\title{
Influence of Participation of School Youth in Decision Making During Showcasing Success Stories by Young Agripreneurs on Implementation of Agricultural Programmes
}

\author{
Martha K. Nyang'au', Washington A. Ochola', Evans A. Basweti ${ }^{2}$, Albert M. Getabu ${ }^{2}$ \\ and Samson N. Maobe ${ }^{2}$ \\ ${ }^{l}$ Department of Agricultural Education and Extension \\ ${ }^{2}$ Faculty of Agriculture and Natural Resources Management, \\ Kisii University, P.O Box 408-40200, Kisii, Kenya \\ Corresponding e-mail: mkemunto@kisiiuniversity.ac.ke
}

\begin{abstract}
School agriculture programme was introduced in secondary education curriculum in Kenya in 1965 and has academic objective to transfer scientific knowledge, and a vocational one to impart skills that would enable youth become self reliant. However, the vocational objective is scantly attained and school youth are inadequate in skills necessary for creation of livelihoods. It is expected that school youth would acquire more and specialized skills for independence through implementation of agricultural programmes such as in showcasing success stories by young agripreneurs. Participation in decision making on the showcasing events would act as motivation for youth to increase implementation of agricultural programmes. However, there is problem of low participation of school youth in decision making on implementation during showcasing success stories by young agripreneurs. This research was conducted to establish the influence of participation of school youth in decision-making during showcasing by young agripreneurs on implementation of agricultural programmes. The study was carried out in extra-county, county and sub-county category of secondary schools offering agriculture subject and, spread in five agro-ecological zones typical of Kenyan farm types, and found in Kisii and Nyamira counties region. Cross-sectional survey design was used. School youth are secondary school form fours taking the subject and implementing KCSE agriculture project. Stratified, purposive, and simple random sampling procedures were used to select a sample of 361 school youth. Data was collected using questionnaires, analyzed by descriptive and inferential statistics at probability level of 0.05 using SPSS version 21. Results show that school youth are well exposed to showcasing success stories by young agripreneurs for acquiring more and specialized implementation skills. It also confirms that gender of youth in school does not make a significant difference in the level of participation in decision making during showcasing events by young agripreneurs. School youth rated five of the six strategies evaluated as very important, and identified some amongst them as more significantly very important than the rest in increasing their participation during showcasing by young agripreneurs. There is a positive significant and linear correlation between level of participation in decision making during showcasing of success stories by young agripreneurs and level of implementation of agricultural programmes by school youth $(R=0.30, p=0.00), p=0.00)$. These findings will be useful in addressing issues of school youth participation in decision making during showcasing by young agripreneurs to motivate others implement agricultural programmes for self reliance.
\end{abstract}

Key words: School Youth, Decision-Making, Showcasing Agripreneurs, Strategies.

\subsection{INTRODUCTION}

School farm is considered as a laboratory for instruction and experimentation in the teaching of agriculture subject. According to Konyango (2015) the strategy that a school offering agriculture must have a demonstration plot was a way of ensuring that the farm is worth being part of teaching facility. The school farm plots serve as an out of classroom laboratory where the students can carry out trials and experiments following classroom activities, and teachers showcase best practices in agriculture. The farm is 
the avenue for promoting agricultural entrepreneurship, which is a key area in the reforms in school agriculture curriculum. It is expected that every student should have a chance to practice entrepreneurial aspects if the vocational objective of agriculture subject is to have impact on self reliance in youth. Skills and scientific knowledge acquired in school agriculture programme are essential in promoting agripreneurship in young people through the systematic adoption of improved production technology and agricultural research findings (Lewa \& Ndung'u, 2012). However, the agriculture teachers have possibly lost the use of demonstration plots as most school farms have been diverted to meet other objectives. Konyango (2015) showed that the school farms exist only in theory, the activities in the farm never show any creativity and only the principals could explain its use. Consequently, the vocational objective of school agriculture programme is inadequately accomplished. The absence of the school farm also implies inadequate showcasing of best production practices and agripreneurship by agriculture teachers. The end result is that form four youth going through secondary school agriculture programme are scantly exposed in the practice of agripreneurship. It is expected that the gap in knowledge and skills could be filled by the youth participating in showcasing events on success stories by young agripreneurs to gain more and specialized skills. Some of the activities that have been applied during showcasing youth successes, innovations and lessons in agripreneurship include: use of media and ICT to promote positive perceptions, success stories, new innovations and lessons learnt; engaging leaders to promote youth in agripreneurship; appointing celebrities to champion youth in agripreneurship; utilizing regional and national agricultural shows to highlight successful youth agripreneurs; creation and strengthening school and community youth clubs to showcase products; awards for youth in agripreneurship as part of national youth competions, and agriculture small-medium enterprise awards (SPC, 2010).

\subsection{Statement of problem}

Participation of youth in showcasing success stories by young agripreneurs would act as motivation for them to increase implementation of agricultural programmes for self reliance. However, there is a problem of low participation of youth in showcasing success stories leading to insufficient motivation to implement agricultural programmes. The low participation of youth has been attributed to their inadequate engagement in decision making on showcasing successes by young agripreneurs. The school agriculture curriculum in Kenya is inadequate in agripreneurship. School farm has been diverted to other uses, and is scarcely available to agriculture teachers for demonstrations and practice of agripreneurship for youth to acquire skills. It is also unavailable for experimentation to remove the negative attitude that young people have towards farming as an occupation. In secondary school education, form fours taking agriculture are instead usually taken to the agricultural shows to learn on success stories from adult exhibitors, and that is in some cases considered to be adequate. In the regional and national, agricultural society of Kenya (A.S.K) exhibitions, there is lack of scheme for young agripreneurs to showcase success stories to inspire youth to implement agricultural programmes for independence. Kenya National youth policy 2006 by the Government of Kenya (GoK) in addition shows lack of strategy on showcasing success stories by young agripreneurs. Therefore, lack of showcasing success by young agripreneurs would be one of those factors hampering motivation in school youth to implement agricultural programmes for self reliance.

\subsection{Objective of the study}

To establish the influence of participation of school youth in decision-making during showcasing success stories by young agripreneurs on implementation of agricultural programmes

\subsection{Hypothesis}

The following hypothesis was tested at probability level 0.05

$\mathrm{Ho}_{1}$ : There is non-significant difference in the participation of school youth in decision-making on showcasing success stories by young agri-preneurs to motivate youth implement agricultural programmes.

\subsection{METHODOLOGY}

\subsection{Study area}

The study was carried out in Kisii and Nyamira counties, southwest Kenya in 2019. It was carried out in five agro-ecological zones (AEZs) as defined by Jaetzold and Schmidt (1982). The zones are typical of farm types found in Kenyan highlands, and therefore representative. Characterization into five agro-ecological zones is done using production potential of the area, cropping, livestock systems and taking into account climatic factors of rainfall and temperature. The farm type zones were used to obtain diverse youth population segments with varied exposures, opportunities and experiences on participation in decision making during showcasing success stories by young people. The farm type zones were adopted as different and unique sampling locations and are as follows:

1) Tea-dairy zone 
2) Tea-coffee zone

3) Maize-pyrethrum zone

4) Coffee-banana zone

5) Marginal-sugarcane zone

\subsection{Study Population}

School youth, included in the study were form four students registered for the Kenya certificate of secondary school examination (KCSE) agriculture subject in 2019, offered by the Kenya National Examination Council (KNEC). School youth are thus involved in implementing school agriculture projects offered for national examinations. As part of school agriculture programme, the youth attend agricultural shows, field learning trips, farm visits and other events meant to showcase success stories in agripreneurship. Such exhibitions are usually by adult farmers and are taken to serve the vocational objective of imparting skills and knowled ge that would be helpful to the learners in creating livelihoods. In this study, the youth were proportionately sampled from the three school categories, spread in the five agro-ecological zones (farm type zones) of Kisii-Nyamira counties region as follows:

1) Extra-county,

2) County,

3) Sub-county.

There were 302 secondary schools in the five farm type zones of which 25 were extra-county, 88 county and 189 sub county schools. Majority of youth attend sub-county school category and are day scholars. The distribution of secondary schools in the five zones is as follows:

tea-dairy zone -76 schools, maize-pyrethrum - 52 schools, tea-coffee area - 48 schools, coffee-banana - 50 schools and, sugarcane zone -76 schools. The population of form four school youth registered for agriculture subject in 2019 KCSE in the three school categories was 6,312 , of which 1,300 were in extra-county, 1,906 in county and 3,106 in sub-county schools.

\subsection{Research Design}

The study adopted ex-post facto research design and a cross sectional survey approach. The design was adopted because the researcher without applying any treatment studied the influence of participation of school youth in decision making during showcasing success stories by young agripreneurs, which is a naturally occurring phenomenon without any manipulation (Cohen, Manion \& Morrison, (2007); and Kothari (2004). Because the study used questionnaires that were administered face to face, a cross-sectional survey design was considered the most convenient research approach.

\subsection{Sample Size and Sampling Procedure}

The study adopted a sample size of 30 schools, according to Mugenda and Mugenda (2003) who suggest 30 cases as the least sample size. From the population of 302 schools and the 30 sample size adopted, proportionate stratified random sampling procedure resulted in 19 sub-county schools, 9 county and 2 extra-county schools to participate in the study. However, to represent extra-county category in each farm type 5 extra-county schools were purposefully sampled in instead of the 2 proportionately arrived at. Using stratified random sampling procedure 8, 6, 5, 6 and 8 schools were sampled from; tea-dairy, maize-pyrethrum, tea-coffee, coffee-banana and sugarcane farm type zone, respectively according to their proportions in the populations. According to the table in Krejcie and Morgan (1970); Kathuri and Pals (1993) which summarizes the population and recommended sample sizes, 361 forms four agriculture youth was the adopted sample size from a population of 6,312 school youth registered for KCSE agriculture subject. Proportionate stratified random sampling technique was used to sample 74, 109, and 178, school youth from extra-county, county and sub county schools respectively. Further, by employing proportionate stratified random sampling 86, 58, 52, 60 and 105 school youth were sampled from tea-dairy, maize-pyrethrum, tea-coffee, coffeebanana and sugarcane chewing and crushing farm types respectively. Simple random sampling procedure was used at school level to select 15,13 and 12 youth from each extra-county, county and sub-county school categories respectively to participate in the study from class lists provided by the agriculture teachers, making a total of 361 respondents.

\subsection{Instrumentation and data collection procedures}

Data was collected using questionnaires because the respondents involved were literate and, therefore could read the questions and respond appropriately by filling. Daniel (2004) indicates that with questionnaires the participants can fill at their own convenience, and that it allows some time for the respondents to familiarize with the questions and think about the answers. The questionnaires used were closed type and had two likert rating scales; one coded from 1 to 10 , where: $1-4=$ low; 5 - $7=$ average and $8-10=$ high levels of participation in decision making. These scales were used to measure the level of participation of youth in decision making during showcasing success stories by young agripreneurs, and level of implementation of agricultural programmes. The other scale used in the study was coded, 1 to 5, where: 1=Not Important; 2=Least important; 3=Important; 4=Very Important, 5=Extremely Important. This was used to rate the six strategies proposed to increase participation of youth in 
decision making on showcasing success stories by young agripreneurs to motivate young people implement agricultural programmes.

\subsection{Data Analysis}

Qualitative and quantitative statistical tools applied in data analysis were: percentages, two tailed t-test, analysis of variance, Tukey post hoc test, Spearman correlation two tailed and linear correlation. The two tailed t- test was used to determine the differences in gender of school youth in decision-making during showcasing success stories by young agripreneurs. The F-test was used to establish if there were significant differences among school youth in decision-making on showcasing success stories as a result of age, agro-ecological zones (farm type zone), and approximate parents' land sizes. Tukey post hoc test was applied in mean separation where there were significant differences. Spearman rank correlation coefficient two tailed test was employed to determine the relationship between the level of participation in decision-making on showcasing success stories by young agripreneurs, and the level of implementation of agricultural programmes. Linear correlation was used to establish the influence of level of participation in decision making by school youth, and level of implementation of agricultural programmes. Tables and a scatter plot graph were used to present the results.

\subsection{RESULTS}

3.1 Level of exposure of school youth to showcasing success stories by agripreneurs to motivate young people implement agricultural programmes by gender

Majority of male $(66 \%)$ and female $(61 \%)$ school youth are exposed to showcasing of success stories by young agripreneurs at high levels of 8 and 10 respectively (Table 1 ).

The t-test result in Table 2 confirms that there is a non-significant difference between male and female school youth $(\mathrm{M}=$ $6.751055, \mathrm{SD}=6.577594)$ and $(\mathrm{M}=6.612903, \mathrm{SD}=6.174141)$; $\mathrm{t}(359)=1.966594, \mathrm{p}=0.623579)$ respectively on the level of exposure to showcasing success stories by young agri-preneurs. Thus, both male and female school youth have almost equal exposure on showcasing events by young agri-preneurs.

Table 1: Cross tabulation on level of exposure of school youth to showcasing success stories on agripreneurship by gender.

\begin{tabular}{lccccccccccc}
\hline Gender & \multicolumn{1}{c}{ Level of exposure in showcasing success stories by young agri-preneurs } & \multicolumn{3}{c}{ Total } \\
& 1.00 & 2.00 & 3.00 & 4.00 & 5.00 & 6.00 & 7.00 & 8.00 & 9.00 & 10.00 & \\
\hline Male & 11 & 4 & 14 & 22 & 25 & 25 & 22 & 44 & 30 & 40 & 237 \\
& & & & & & & & & & & \\
Female & 5 & 3 & 4 & 17 & 10 & 19 & 14 & 22 & 9 & 21 & 124 \\
Total & 16 & 7 & 18 & 39 & 35 & 44 & 36 & 66 & 39 & 61 & 361 \\
\hline
\end{tabular}

Table 2: T-test results on the difference of school youth on level of exposure to showcasing success stories of young agri-preneurs by gender

\begin{tabular}{lllllll}
\hline Respondents & $\mathrm{n}$ & $\begin{array}{l}\text { Participation } \\
\text { mean score }\end{array}$ & (Std Dev.) & $\mathrm{df}$ & $\mathrm{t}$-value & $\mathrm{P}$ - value \\
\hline Male & 237 & 6.751055 & 6.577594 & 359 & 1.966594 & 0.623579 \\
Female & 124 & 6.612903 & 6.174141 & & & \\
\hline
\end{tabular}

\subsection{Level of consultation of school youth on showcasing success stories of young entrepreneurs by gender}

Majority of male (67\%) and female (64\%) school youth indicated their being consulted on showcasing success stories by young agripreneurs at the high levels of 8 and 10, respectively (Table 3). However, t-test result confirmed a non-significant difference between school male and female youth $(\mathrm{M}=6.818565, \mathrm{SD}=5.928806)(\mathrm{M}=6.669355, \mathrm{SD}=5.39385) ; \mathrm{t}(359)=1.966594, \mathrm{p}$ $=0.574704$ ) respectively in the level of consultation on showcasing success stories of young agri-preneurs (Table 4). 
Table 3: Cross tabulation on level of consultation of school youth on choosing success stories of youth agripreneurs on exposure by gender

\begin{tabular}{llllllllllll}
\hline Gender & \multicolumn{4}{c}{ Level of consultation on choosing success stories for exposure } & \multicolumn{4}{c}{ Total } \\
& 1.00 & 2.00 & 3.00 & 4.00 & 5.00 & 6.00 & 7.00 & 8.00 & 9.00 & 10.00 & \\
\hline Male & 8 & 6 & 8 & 15 & 37 & 33 & 20 & 45 & 21 & 44 & 237 \\
& & & & & & & & & & & \\
Female & 3 & 5 & 5 & 4 & 21 & 18 & 20 & 22 & 6 & 20 & 124 \\
Total & 11 & 11 & 13 & 19 & 58 & 51 & 40 & 67 & 27 & 64 & 361 \\
\hline
\end{tabular}

Table 4: T test results on the difference amongst school youth on level of consultation on showcasing success stories of young agri-preneursn for exposure by gender

\begin{tabular}{lllllll}
\hline Respondents & $\mathrm{n}$ & $\begin{array}{l}\text { Participation } \\
\text { mean score }\end{array}$ & (Std Dev.) & $\mathrm{df}$ & $\mathrm{t}$-value & $\mathrm{P}$ - value \\
\hline Male & 237 & 6.818565 & 5.928806 & 359 & 1.966594 & 0.574704 \\
Female & 125 & 6.669355 & 5.39385 & & & \\
& & & & & &
\end{tabular}

\subsection{Rating of strategies proposed to increase participation of school youth in decision making during showcasing success stories} by young agripreneurs

The F-test result in Table 5 confirms that there is a significant difference $(\mathrm{F}=23.69499$, $\mathrm{p}$ value $<.01)$ among the strategies proposed to increase school youth participation in decision making during showcasing success stories by young agripreneurs. Tukey post hoc test results in Table 6 corroborate that school youth rated five out of the six strategies proposed as very important in increasing their participation in decision making during showcasing success stories by young agripreneurs. With the exception of strategy 1 and 2 all the other strategies namely 5, 4, 6 and 3 were ranked as very important with mean scores of $3.5-4.5$ (Table 6). Tukey post hoc test confirmed that strategies 5, 4, 6 and 3 are similar but more significantly very important than 1 and 2 as they have higher mean ratings.

Table 5: Analysis of variance F-test results on the differences in ratings of strategies proposed to increase participation of school youth in decision making during showcasing success stories by young agripreneurs

\begin{tabular}{lllllll}
\hline Source of Variation & SS & $d f$ & $M S$ & $F$ & P-value & F crit \\
\hline Between Groups & 160.9178 & 5 & 32.18356 & 23.69499 & 0.00 & 2.21824 \\
Within Groups & 2933.806 & 2160 & 1.358244 & & & \\
& & & & & \\
Total & 3094.724 & 2165 & & & \\
\hline
\end{tabular}

Table 6: Tukey post hoc test results on the differences in ratings of strategies proposed to increase participation of school youth in decision making during showcasing success stories by young agripreneurs

\begin{tabular}{|c|c|c|c|c|}
\hline \multirow[t]{2}{*}{ No. } & \multirow[t]{2}{*}{$\begin{array}{l}\text { Strategies proposed to increase participation of school youth in decision making on } \\
\text { showcasing success stories by young agripreneurs }\end{array}$} & \multirow[t]{2}{*}{$\mathrm{N}$} & \multicolumn{2}{|c|}{$\begin{array}{l}\text { Subset for alpha }= \\
0.05\end{array}$} \\
\hline & & & 1 & 2 \\
\hline 1 & $\begin{array}{l}\text { Re-branding of agriculture with trendy names that appeal to youth will change their poor } \\
\text { perception of the sector and embrace agriculture }\end{array}$ & 361 & 3.3850 & \\
\hline 2 & $\begin{array}{l}\text { Successful youth agri-preneurs to conduct campaigns in rural areas to demystify the notion } \\
\text { that agriculture is for the old and uneducated people in society }\end{array}$ & 361 & 3.5873 & \\
\hline 3 & $\begin{array}{l}\text { Public education by young agri-preneurs to sensitize schools on proper usage of the school } \\
\text { farm to a void portraying agriculture career as punishment }\end{array}$ & 361 & & 3.9391 \\
\hline
\end{tabular}


International Journal of Research in Social Science and Humanities (IJRSS), Vol .1(4), Sep-Oct- 2020

\begin{tabular}{|l|l|c|c|}
\hline 6 & $\begin{array}{l}\text { The media to showcase communities that guard against ridicule of youth in agriculture and } \\
\text { protect the their agribusiness activities from being vandalized }\end{array}$ & 361 & 4.0222 \\
\hline 4 & $\begin{array}{l}\text { Public-private award scheme that will recognize and reward successful youth agri-preneurs } \\
\text { and thus motivate those interested in agriculture }\end{array}$ & 361 & 4.0277 \\
\hline 5 & $\begin{array}{l}\text { Forming agribusiness clubs at community level where successful agri-preneurs can mentor } \\
\text { out of school youth, share ideas, experiences and showcase their success }\end{array}$ & 361 & \\
\hline Sig. & .137 \\
\hline
\end{tabular}

\subsection{Relationship between level of participation in decision making during showcasing success stories by young agripreneurs and level of implementation of agricultural programmes by school youth}

The regression correlation results (Tables 7 and 8 ) indicate that there is a significant positive correlation $(\mathrm{R}=0.3, \mathrm{p}<.0 .01)$ between the level of participation of school youth in decision making during showcasing success stories by young agripreneurs and level of implementation of agricultural programmes. The finding supports that school youth are likely to participate more in the implementation of agricultural programmes as a result of being exposed further to showcasing of success stories of young agri-preneurs. The linear correlation test result (Figure 1) shows that showcasing success stories of young agripreneurs to school youth accounts for $30 \%\left(\mathrm{R}^{2}=0.3\right)$ increase in their level of participation in implementation of agricultural programmes, with the remaining $70 \%$ being explained by other factors.

Table 7: Regression results on level of participation in decision making during showcasing success stories by young agripreneurs and level of implementation of agricultural programmes by school youth.

\begin{tabular}{lc}
\hline Regression Statistics & \\
\hline Multiple R & 0.54777033 \\
R Square & 0.300052334 \\
Adjusted R Square & 0.298102619 \\
Standard Error & 2.123734202 \\
Observations & 361 \\
\hline
\end{tabular}

Table 8: Correlation coefficient results on level of participation of school youth in decision making during showcasing success stories by young agri-preneurs and level of implementation of agricultural programmes

\begin{tabular}{lllllllll}
\hline & & Standard & & $\begin{array}{l}P- \\
\text { value }\end{array}$ & $\begin{array}{l}\text { Lower } \\
95 \%\end{array}$ & $\begin{array}{l}\text { Upper } \\
95 \%\end{array}$ & $\begin{array}{l}\text { Lower } \\
95.0 \%\end{array}$ & $\begin{array}{l}\text { Upper } \\
95.0 \%\end{array}$ \\
\hline Intercept & 2.652925529 & 0.345125 & 7.68685 & 0.00 & 1.974204 & 3.331647 & 1.974204 & 3.331647 \\
X Variable 1 & 0.559408525 & 0.045094 & 12.40546 & 0.00 & 0.470727 & 0.64809 & 0.470727 & 0.64809 \\
\hline
\end{tabular}




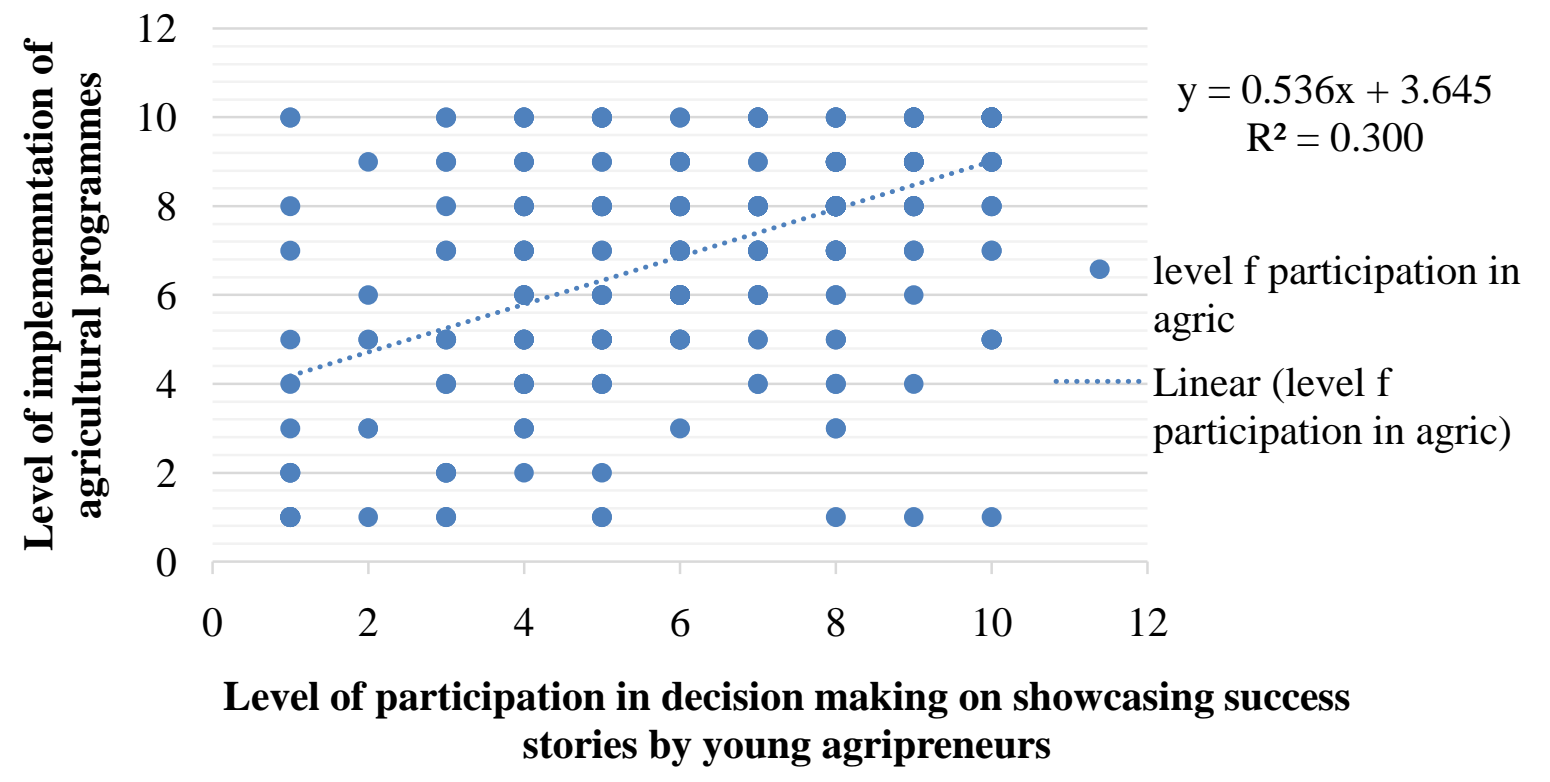

Figure 1: Scatter plot on level of participation in decision making on showcasing success stories by young agripreneurs and level of implementation of agricultural programmes by school youth

\section{0 DISCUSSION}

4.1 Influence of gender of school youth on level of participation in decision making during showcasing success stories by young agripreneurs

The t-test result in Table 2 shows a non-significant difference between male and female school youth on participation in decision making during showcasing success stories by young agriprenuers. The observation is within expectation because school agriculture students irrespective of their gender are under the same learning environment. So, there is no special preference given to either gender hence the similarly in exposure to showcasing success stories by young agripreneurs. For instance when students are taken out of classroom for field visits, agricultural shows, learning trips, there is no discrimination or a special preference given to any of the gender. They all get exposed similarly to success stories by young agri-preneurs and have the same opportunity to engage in the learning activity without any bias. Consequently, gender does not affect the level of exposure of school youth to showcasing of success stories by young agri-preneurs. For school youth therefore, gender is unlikely to influence implementation of agricultural programmes on account of exposure to showcasing success stories.

\subsection{Influence of gender of school youth on level of participation in decision making on consultation during showcasing success stories by young entrepreneurs}

There is a non-significant difference between male and female school on level of participation in decision making on consultation during showcasing success stories by young agri-preneurs (Table 4). The results suggest that school agriculture teachers probably rarely consult with learners on showcasing success stories by young agripreneurs as means to acquire more and specialized skills for self reliance. The result corroborate that this aspect of school agriculture is possibly neglected. Therefore the gender of school youth does not influence the level of consultation in showcasing agripreneurship. The KIE school agriculture curriculum scantly covers agripreneurship yet it is meant to contribute towards enabling youth to create livelihoods for independence hence the need for its reforms.

\subsection{Rating of strategies proposed to increase participation of youth in decision making during showcasing success stories by young agripreneurs}

Tukey post hoc test indicates that strategies 5, 4, 6 and 3 are similar but more significantly very important than the rest as they have a higher rank (Table 6). Strategy 5 which also is the subject of this study, advocates for forming agribusiness clubs at community level where successful agri-preneurs can mentor school youth, share ideas, experiences and showcase their successes. Strategy 4 supports the formation of a public-private award scheme that would recognize and reward successful youth agripreneurs and thus motivate those interested in agriculture. Strategy 6 states that the media should showcase communities that guard against ridicule of youth in agriculture and protect their agribusiness activities from being vandalized. Strategy 3 proposes 
public education by young agri-preneurs to sensitize schools on proper usage of the farm to a void portraying agriculture career as punishment. From the results, it is notable that school youth are in concurrence that strategies 5, 6, 4 and 3 are more significantly very important than the rest.

\subsection{Relationship between level of participation of school youth in decision making during showcasing success stories by young agripreneurs and level of implementation of agricultural programmes}

There is a significant positive linear correlation between the level of participation of youth in decision making during showcasing success stories by young agripreneurs and level of implementation of agricultural programmes (Table 15, Figure 1). Showcasing success stories of young agripreneurs to school youth accounts for $30 \%\left(\mathrm{R}^{2}=0.3\right)$ increase in their level of implementation of agricultural programmes, with the remaining $70 \%$ being explained by other factors. The results are in line with Cheteni (2018) who found a positive correlation between youth programmes, resources and participation in programme activities. The finding corroborate that school youth are likely to participate more in implementation of agricultural programmes as a result of being exposed further to showcasing success stories by young agri-preneurs.

\subsection{CONCLUSIONS}

1) School youth are well exposed to participation in decision making in showcasing success stories by young agripreneurs

2) Gender of school youth does not make a significant difference in level of participation in decision making in showcasing success stories by young agripreneurs

3) School youth are in concurrence that strategies 5, 6, 4 and 3 are more significantly very important than the rest in increasing their participation in decision making in showcasing success stories by young agripreneurs

4) There is a positive significant linear correlation between level of participation in decision making during showcasing of success stories of young agripreneurs and the level of implementation of agricultural programmes by school youth $(\mathrm{R}=0.30$, $\mathrm{p}=0.00)$.

\subsection{Recommendations}

These findings are useful in addressing school youth issues on participation in decision making during showcasing success stories of young agripreneurs to motivate others implement agricultural programmes to improve effectiveness in transfer of knowledge, more and specialized skills to enhance self reliance in young people.

\section{Acknowledgements}

This article is extract of the objective five of $\mathrm{PhD}$ thesis of the first author. We are grateful to the Vice Chancellor, Kisii University for providing a study leave to the main author. We are also grateful to the Department of Agricultural Education and Extension, and Dean, Faculty of Agricultural and Natural Resources Management for availing facilities that enabled this research work to be done.

\section{REFERENCES}

Abdullah, A. A., \& Terengganu, K. (2013). Factors That Influence the Interest of Youths in Agricultural Entrepreneurship. 4(3), 288-302.

Buragohain, M., Bordoloi, N., Lego, I., Hussian, H. M., \& Saikia, D. (2018). A Study on Relationship between Extent of Participation in Decision Making Activities, with Socio-Economic and Psychological Characteristics of Rural Youths towards Farming in Jorhat District of Assam. International Journal of Agriculture Sciences(IJAS), $10(3), 5115$. https://doi.org/10.9735/0975-3710.10.3.5115-5117

Cheteni, P. (2018). econstor. September 2016. https://doi.org/10.1080/09709274.2016.11907025

Lohento, K., \& Mayenga, D. (2015). Youth in Agribusiness within an African Agricultural Transformation Agenda. An Action Plan for African Agricultural Transformation

Muthomi, E. (2017). Challenges and Opportunities for Youth Engaged in Agribusiness in Kenya. 